\title{
Kepentingan Pemerintah Pusat Dalam Pembangunan Infrastruktur Perbatasan Kalimantan Indonesia-Malaysia Era Presiden Susilo Bambang Yudhoyono
}

\author{
Saiman ${ }^{*}$ \\ saimanmhdris@gmail.com
}

\begin{abstract}
Abstrak
Ketertinggalan pembangunan di Kalimantan merupakan salah satu penyebab terjadinya permasalahan perbatasan Kalimantan Indonesia-Malaysia. Berdasarkan Undang-Undang tentang Wilayah Negara, negara bertanggung jawab dalam pembangunan perbatasan guna pencapaian masyarakat perbatasan yang sejahtera dan aman. Tulisan ini mengkaji kepentingan pemerintah pusat pada prioritas kebijakan dan kepentingan, peran dan power interplay antar lembaga serta nasionalisme. Berdasarkan metode kualitiatif dengan studi kasus, bahwa peran Pemerintah (BNPP) hanya sebagai lembaga koordinatif, terjadi ego sektoral antar lembaga. Kekuasaan pemerintah pusat sangat dominan, prioritas kebijakan dan kepentingan pemerintah meliputi faktor politik, keamanan dan strategis geografi, sehingga terjadi perubahan orientasi nasionalisme masyarakat perbatasan.
\end{abstract}

Kata Kunci: kepentingan nasional, pemerintah pusat; pembangunan infrastruktur; perbatasan.

\begin{abstract}
Underdevelopment in Borneo was one of cause Indonesia-Malaysia border problems. According State Territorial Policy, state was to responsibility in border development for receive border komunities which prosperous and secure. This paper to test central and local government relatios desentralisation era at policy priority and interests, role and power interplay of institutions, and nasionalism. According qualitative method and case studi, that government role as the coordinating institution, sectoral ego bithwin other institutions. Central government power very dominant and priority in policy and intersts central government, include politics factor, security and geografi strategic, so that happen orientation changes communities nationalism.
\end{abstract}

Keywords: borderland, central government, infrastructure development, national interests.

\section{Pendahuluan}

Kawasan perbatasan memiliki peran sangat penting dan strategis, karena merupakan wilayah suatu negara yang menjadi batas kedaulatan negara dengan negara lain. Perbatasan juga merupakan wilayah yang merefleksikan halaman depan suatu negara, namun seringkali menimbulkan permasalahan yang sangat kompleks. Salah satu faktor penyebab terjadinya permasalahan kawasan perbatasan adalah akibat ketertinggalan pembangunan dengan negara tetangga. Indonesia memiliki wilayah perbatasan yang sangat luas dan berbatasan dengan 10 negara yaitu Malaysia, Papua

\footnotetext{
* Korespondensi: Prodi Ilmu Pemerintahan, FISIP, Universitas Muhammadiyah Malang, Tlp. (0341) 464318 Fax (0341) 460435.
} 
Nugini, Singapura, Republik Demokratik Timor Leste, India, Thailand, Vietnam, Filipina, Republik Palau dan Australia. Peran negara (pemerintah pusat) sangat dibutuhkan dalam pembangunan, menjaga keamanan kawasan perbatasan dan kedaulatan NKRI. Namun pemerintah pusat mengalami kendala dalam pelaksanaan pembangunan kawasan perbatasan.

Perbatasan Kalimantan adalah salah satu wilayah perbatasan Indonesia yang berbatasan dengan Malaysia sepanjang $2.004 \mathrm{~km}$ yang sering menimbulkan permasalahan antar negara. Permasalahan yang terjadi mulai dari yang bersifat sosial budaya seperti mengunjungi kerabat saudara di Malaysia tanpa dokumen resmi, masalah ekonomi seperti perdagangan ilegal, masalah politik dan keamanan seperti konflik antar negara yang dapat mengancam stabilitas perbatasan, nasionalisme dan kedaulatan NKRI.

Puncak masalah politik terjadi pada tanggal 17 Desember 2002, Mahkamah Internasional memutuskan bahwa Pulau Sipadan dan Ligitan menjadi milik Malaysia. Pulau yang berjarak 15 mil sebelah timur, sehingga mempengaruhi perubahan batas negara dan akitivitas nelayan Kabupaten Nunukan. Tahun 2005, Malaysia mengklaim Blok Ambalat di Laut Sulawesi, sehingga terjadi manuver militer IndonesiaMalaysia (Madu, 2010:234). Tahun 2005, juga terjadi pergeseran patok batas IndonesiaMalaysia di Desa Aji Kuning Kecamatan Sebatik Kabupaten Nunukan pada 4¹0’ LU hasil perjanjian Inggris dan Belanda tahun 1928, sehingga selisih 4" yang berarti Indonesia kehilangan wilayah sekitar 103 hektar dan belum disepakati Malaysia (Iva Rachawati dalam Ludiro Madu, 2010:96). Pada tahun 2014, Malaysia mengklaim tiga desa yakni Desa Sinapadat, Simantipal dan Sinokod di Kecamatan Lumbis Kabupaten Nunukan merupakan wilayah Malaysia (Republika, 15 November 2014). Sekitar 20 dari 85 kepala keluarga di Desa Samunti Lumbis memiliki kartu identitas Malaysia (Mykad) dan pindah ke Malaysia, karena desakan ekonomi, kebutuhan pendidikan dan minimnya pelayanan kesehatan (Republika, 15 November 2014).

Permasalahan perbatasan di Kalimantan sangat mengganggu kedaulatan NKRI. Hal ini terjadi karena keterbatasan kemampuan pengamanan wilayah perbatasan dan kondisi sosial ekonomi masyarakat yang masih rendah serta akibat ketertinggalan pembangunan dengan negara Malaysia, sehingga terjadi lalu lintas orang, barang dan sumber daya alam yang merugikan NKRI. Meskipun saat ini perhatian 
pemerintah pusat terhadap isu-isu pembangunan perbatasan telah meningkat, namun secara faktual pembangunan perbatasan masih terdapat sejumlah masalah. Pembangunan perbatasan sangat penting karena berkaitan dengan nasionalisme dan kedaulatan NKRI.

Kalimantan merupakan daerah yang sangat kaya sumber daya alam dan strategis secara geopolitik (Magenda, 1991:4). Perbatasan Kalimantan sangat memerlukan perhatian pemerintah pusat (negara) dalam pembangunan perbatasan, karena tiga dari lima provinsi di Kalimantan berbatasan dengan Malaysia (Peraturan Presiden RI Nomor 31 Tahun 2015:9). Posisi Kalimantan sangat penting dan strategis karena menjadi pintu gerbang bagi lalu lintas barang dan jasa, serta mobilitas penduduk, baik untuk kepentingan bisnis maupun tenaga kerja antara Indonesia dan Malaysia (Magenda, 1991:4). Masyarakat perbatasan lebih berorientasi kepada Malaysia, karena memiliki akses yang lebih baik sehingga masyarakat merasa lebih dekat, lebih mudah dan lebih murah daripada ke ibukota Kabupaten dan provinsi yang lebih jauh jaraknya.

Berdasarkan Undang-Undang RI Nomor 43 Tahun 2008 tentang Wilayah Negara dan Peraturan Presiden (Perpres) Nomor 12 Tahun 2010 tentang Badan Nasional Pengelolaan Perbatasan (BNPP), BNPP mempunyai tugas melaksanakan pembangunan perbatasan sesuai dengan Perpres Nomor 5 Tahun 2010 tentang Rencana Pembangunan Jangka Panjang Menengah Nasional (RPJMN) tahun 20102014 dengan prioritas pembangunan bidang pendidikan, kesehatan, penanggulangan kemiskinan, infrastruktur daerah tertinggal, terdepan, terluar dan pasca konflik (Peraturan Presiden RI Nomor 5 Tahun 2010). Kebijakan prioritas nasional ini menunjukkan adanya komitmen pemerintah pusat untuk melakukan pembangunan di perbatasan agar permasalahan perbatasan segera diselesaikan dan tidak menjadi ancaman bagi kedaulatan NKRI sesuai dengan visi terwujudnya perbatasan negara sebagai wilayah yang aman, tertib, dan maju (Peraturan BNPP Nomor 1 Tahun 2011:16-18) dengan pendekatan secara komprehensif pada tiga dimensi yaitu kesejahteraan, keamanan dan lingkungan (Peraturan BNPP Nomor 1 Tahun 2011:25).

Namun dalam konteks hubungan pemerintah pusat dan daerah, pelaksanaan kebijakan pembangunan infrastruktur perbatasan Era Pemerintahan Presiden SBY tahun 2009-2014 di Kalimantan mengalami beberapa masalah. Permasalahan pertama adalah tentang BNPP sebagai lembaga representasi negara yang 
mempunyai kekuasaan dalam pembangunan perbatasan berdasarkan Undang-Undang Wilayah Negara, tetapi mengapa peran pemerintah (BNPP) hanya sebagai lembaga yang bersifat koordinatif (Peraturan Presiden Nomor 12 Tentang BNPP Pasal 3). Sementara penyelesaian permasalahan pembangunan perbatasan sangat penting. Pemerintah Pusat bekerja sama dengan TNI-AD pada pembangunan perluasan Bandara Yuvai Semaring di Krayan dan jalan di Kalimantan menunjukkan sistem kelembagaan masih bersifat sentralis. Bahkan tidak dilakukan oleh Kementerian Perhubungan atau Kementerian Pekerjaan Umum, sebagaimana umumnya yang menjadi tanggung jawab kementerian tersebut, atau dilimpahkan (didelegasikan) kepada pemerintah daerah dan BPPD. Maka, bagaimana power interplay BNPP dengan lembaga negara lainnya dan Pemerintah Daerah Provinsi dan Pemerintah Daerah Kabupaten.

Permasalahan kedua adalah mengapa terjadi perbedaan dalam prioritas kebijakan program pembangunan infrastruktur oleh Pemerintah Pusat dengan kepentingan masyarakat perbatasan, dan apa kepentingan Pemerintah Pusat membangun perluasan bandara dan jalan serta kerja sama dengan TNI-AD. Kepentingan Pemerintah Pusat fokus pada kepentingan nasional dari aspek politik dan keamanan, sementara masyarakat perbatasan mengharapkan mudahnya akses pada pelayanan dasar dan kesejahteraan.

Tujuan tulisan ini untuk mengetahui kepentingan Pemerintah Pusat dalam pembangunan infrastruktur perbatasan di Kalimantan Indonesia-Malaysia era Presiden SBY 2009-2014 pada peran Pemerintah Pusat (BNPP) dan power interplay antar lembaga, prioritas kebijakan dan kepentingan pemerintah pusat.

\section{Kajian Pustaka}

Kajian tentang kepentingan pemerintah pusat dalam pembangunan infrastruktur perbatasan Kalimantan Indonesia-Malaysia era Presiden Susilo Bambang Yudhoyono Tahun 2009-2014 menggunakan teori negara dan hubungan pusat dan daerah sebagai teori utama, sedangkan teori kebijakan, konflik kewenangan pusat dan daerah, dan nasionalisme sebagai teori pendukung kajian ini. 
Berdasarkan teori negara, Indonesia sebagai sebuah negara yang merdeka dan berdaulat punya kewajiban dan tanggung jawab membangun dan menjaga keamanan perbatasan wilayahnya. Ralph Miliband mengatakan bahwa:

The state is an institution which have authority, those political leaders who have generally political authority been able to gain high office have very seldom managing for government institutions at excutive, legislative and yudicative institution (Ralph Miliband, 1969:69).

Pandangan Miliband, melihat bahwa negara sebagai pemilik kekuasaan (otoritas), state centre yang dijalankan oleh pemimpin politik (elit negara) yang mempunyai pertimbangan untuk menentukan kebijakan dan tidak hanya didikte oleh kelas dominan (Wetherly, 2005:29), melalui institusi untuk mengatur dan mengendalikan permasalahan bersama yakni ketertinggalan pembangunan kawasan perbatasan. Sehingga negara harus segera melaksanakan pembangunan demi kepentingan nasional dan kedaulatan NKRI, karena pembangunan perbatasan adalah kewajiban negara dan berkaitan dengan kedaulatan negara.

Kepentingan nasional menurut Donald E.Neuchterlin meliputi 4 jenis yaitu: Pertama, kepentingan pertahanan yang berisi tentang kepentingan negara untuk melindungi warga negaranya, kawasan teritorial serta sistem politik dari ancaman negara lain; Kedua, kepentingan ekonomi yakni kepentingan pemerintah untuk meningkatkan perekonomian negaranya melalui hubungan dengan negara lain; Ketiga, kepentingan tata internasional yakni kepentingan untuk mewujudkan politik serta ekonomi internasional yang menguntungkan bagi negaranya; dan Keempat, kepentingan ideologi yaitu kepentingan untuk melindungi dan mempertahankan ideologi negaranya dari ancaman ideologi negara lain (Bakri, 1999:62).

Selanjutnya, Miroslav Nincic memperkenalkan tiga asumsi dasar yang harus dipenuhi dalam mendefinisikan kepentingan nasional. Pertama, kepentingan harus bersifat vital sehingga pencapaiannya harus menjadi prioritas pemerintah dan masyarakat; Kedua, kepentingan nasional tersebut harus berkaitan dengan kepentingan internasional; Ketiga, kepentingan nasional harus melampaui kepentingan yang bersifat partikularistik dari individu, kelompok serta lembaga pemerintahan, sehingga kepentingan nasional tersebut dapat menjadi kepedulian masyarakat umum yang akan bersama-sama mencapainya dengan pemerintah. (Jemadu, 2008:67). 
Selanjutnya, Theda Skocpol (1991:21) mengatakan bahwa negara dipandang sebagai tidak lebih dari suatu arena konflik kepentingan sosial dan ekonomi yang saling berbenturan satu sama lain. Negara disebut sebagai arena politik disebabkan para aktor yang beroperasi di dalam arena tersebut dalam melakukan konflik sosial dan ekonomi menggunakan sarana yang berbeda-beda seperti paksaan atau slogan-slogan yang mendengungkan kebijakan umum. Negaralah yang menjadi aktor utama dan sering kali menjadi aktor tunggal dalam kehidupan politik sejak negara membatasi dan mempengaruhi agenda masyarakat. Fungsi dasar dari semua negara adalah untuk memelihara hukum dan ketertiban, dan membangun kapital bagi dirinya sendiri (Chandhoke, 1995:69-70). Jadi negara adalah arena dari otoritas yang absah yang diwujudkan dalam bentuk aturan permainan politik dan kepemimpinan pemerintahan serta kebijakannya (Skocpol, 1991:21).

Dalam perspektif teori hubungan Pusat-Daerah dan konflik kekuasaan, bahwa negara kesatuan adalah konsep ketatanegaraan yang mengatur hubungan kekuasaan antara pemerintah pusat dan pemerintah daerah (Sekretariat Jenderal MPR RI, 2012:167). Indonesia sebagai negara kesatuan mendistribusikan kekuasaan berdasarkan hubungan pemerintah pusat dan daerah. Hubungan pusat dan daerah di Indonesia dikaitkan dengan desentralisasi dan otonomi daerah. Brian C. Smith menyebutkan konsep desentralisasi dalam studi politik sebagai berikut :

In the study of politics decentralization refers to the territorial distribution of power. It is concerned with the extent to which power and authority are dispersed through the geographical bierarchy of the state and the institutions and processes through which such dispersal occurs. Decentralization entails the subdivision of the states territory into smaller areas and the creation of political and administrative institutions in those areas. (Brian C. Smith, 1985:1).

Selanjutnya Smith menjelaskan bahwa pelaksanaan desentralisasi tidak hanya ditujukan untuk kepentingan pemerintah pusat, melainkan juga dalam rangka kepentingan lokal. Kepentingan pemerintah daerah antara lain adalah terwujudnya persamaan politik (political equality), munculnya pemerintahan lokal yang bertanggung jawab (local accountability), dan responsivitas masyarakat setempat (local responsiveness) terhadap masalah-masalah obyektif masyarakat di tingkat lokal (Brian C. Smith, 1985:19-29). Dengan demikian kebijakan pembangunan perbatasan sangat dipengaruhi 
oleh kepentingan pemerintah pusat dan daerah, sebagai wujud distribusi kekuasaan pemerintah pusat kepada pemerintah daerah.

Rondinelli dan Cheema selanjutnya menegaskan bahwa :

...desentralisation is the transfer of planning, decision making, or administrative authority from central goverment to its field organisations, local administrative units, semi autonomous and parastatal organisations, local government, or non-government organisations. (Cheema, G. Shabbir and Dennis Rondinelli, 1983:18).

Secara umum struktur pemerintahan Indonesia tetap merefleksikan sistem pengambilan keputusan top-down, di mana kekuasaan terpusat di tangan pejabat tingkat atas pada setiap level pemerintahan, baik di pemerintah pusat, pemerintahan provinsi, kabupaten maupun desa (MacAndrwes,1993:13). Studi hubungan pusat dan daerah melibatkan lembaga pemerintahan dan interaksi aktor-aktor pemerintah mulai dari pemerintah pusat, pemerintah provinsi dan pemerintah daerah kabupaten/kota dalam menjalankan peran dan fungsi masing-masing (Budiarjo, 2004:47-56).

Selanjutnya pada perspektif politik, kebijakan merujuk pada proses interaksi struktural fungsional pemerintahan yang memiliki otoritas untuk mengambil kebijakan, mekanisme formulasi dan adopsi kebijakan. Jadi kebijakan dapat sebagai aktivitas elit politik pemerintah untuk merespons atau tidak merespons terhadap isuisu masalah. Kebijakan sebagai perilaku dari sejumlah aktor (pejabat, kelompok, instansi pemerintah) atau serangkaian aktor dalam suatu bidang kegiatan tertentu (Anderson, 1978:2). W.I. Jenkins mengatakan bahwa kebijakan adalah :

a set of interrelated decisions taken by a political actor or group of actor concerning the selection of goals and the means of achieving them within a specified situation where these decisions should, in principle, be within the power of these actors to achieve. (Jenkins, 1978:15).

Pembangunan perbatasan berkaitan erat dengan nasionalisme dan kedaulatan bangsa, mengingat bahwa konsep negara-nasional bermula dari perspektif tentang bangsa. Menurut Ernest Renan, bangsa adalah jiwa, suatu asas kerohanian yang timbul dari kemuliaan bersama di waktu lampau, yang merupakan aspek historis dan keinginan untuk hidup bersama pada masa sekarang yang merupakan aspek solidaritas dan juga di masa yang akan datang (Heaton dan Renan, 1990:243).

Sedangkan menurut Kellas, "nation" adalah sekelompok orang yang menyatakan diri mereka sebagai bagian dari masyarakat dan secara bersama-sama 
dibatasi oleh pertalian sejarah, budaya dan keturunan. Nation memiliki karakteristik yang sifatnya objektif maupun subjektif. Karakteristik objektif meliputi wilayah, bahasa, agama. Sedangkan karakteristik subjektif adalah kesadaran orang terhadap kebangsaannya dan rasa cintanya terhadap kebangsaannya itu. Kellas memaknai nasionalisme sebagai ideologi dan bentuk dari perilaku atau tindak-tanduk sebuah nation. Ideologi ini dibangun atas kesadaran rakyat terhadap bangsanya dalam hal pernyataan sebuah sikap dan perilaku. Ketika seseorang atau sekelompok orang menunjukkan sikap dan prilaku demi kepentingan nation-nya, mereka tersebut telah menunjukkan nasionalismenya (Kellas,1998:3-9).

\section{Metode Penelitian}

Penelitian ini menggunakan metode kualitatif dengan studi kasus di Perbatasan Kalimantan Indonesia-Malaysia Era Pemerintahan Presiden SBY tahun 2009-2014. Pengumpulan data menggunakan teknik wawancara pada sumber data terkait dan studi kepustakaan. Analisis data menggunakan analisis kualitatif induktif yang berdasarkan data-data dan informasi serta keterangan yang diperoleh dari sumber data primer maupun sumber data sekunder serta dokumentasi yang terkait.

\section{Hasil dan Pembahasan}

Hasil penelitian yang ditemukan pada dua pemasalahan utama penelitian tentang kepentingan Pemerintah Pusat dalam pembangunan infrastruktur perbatasan Kalimantan Indonesia-Malaysia Era Presiden SBY tahun 2009-2014 adalah sebagai berikut:

Pertama, Proses politik lahirnya BNPP, merupakan amanah dari UU Nomor 43 Tahun 2008 Tentang Wilayah Negara Pasal 1 ayat 11 dan Peraturan Presiden Nomor 12 Tahun 2010 Tentang BNPP Pasal 1 ayat 3. BNPP dibentuk sebagai respons pemerintah atas dinamika dan situasi politik serta tuntutan kebutuhan obyektif untuk mempercepat upaya penanganan ketertinggalan perbatasan dan tanggung jawab negara terhadap permasalahan pembangunan di perbatasan. Kebijakan tersebut memberikan kekuasaan yang besar bagi BNPP untuk melakukan pembangunan perbatasan. Hal ini juga terlihat dengan keanggotaan BNPP yang terdiri dari 3 Menko 
dan 15 kementerian dan lembaga negara (Peraturan Presiden Nomor 12 Tahun 2010 Pasal 6).

Namun demikian dalam pelaksanaan tugas BNPP hanya bersifat sebagai lembaga koordinatif (Peraturan Presiden Nomor 12 Tahun 2010 Pasal 3), karena pelaksana teknis pembangunan batas wilayah negara dan kawasan perbatasan dilakukan kementerian, lembaga pemerintah non kementerian, pemerintah provinsi dan pemerintah kabupaten/kota (Peraturan Presiden Nomor 12 Tahun 2010 Pasal 6). Sehingga BNPP tidak dapat melakukan pembangunan perbatasan secara maksimal. Kondisi ini menjadi kendala bagi BNPP untuk mempercepat upaya penanganan ketertinggalan perbatasan yang meliputi 13 provinsi, 41 kabupaten dan 187 kecamatan. Hal ini menunjukkan adanya ketidaksesuaian (sinkronisasi) pada kebijakan Pemerintah Pusat dengan Undang-Undang. Menteri Pertahanan Purnomo Yusgiantoro yang menyatakan bahwa :

...Karena ini masalah, kebanyakan BNPP ini koordinasi saja. Jadi sekarang itu kalau kita lihat yang masih outstanding, jadi kalau yang sudah, bordernya itu sudah jelas. ...jadi sebetulnya BNPP satu forum koordinasi. Jadi dia bukan suatu badan yang sifatnya kohesif mempunyai unsur komando, ini cuman forum koordinasi saja. (Moeldoko, 2014: 411).

Pemerintah Pusat bekerjasama dengan TNI-AD pada pembangunan perluasan Bandara Yuvai Semaring di Krayan dan jalan perbatasan Kalimantan (Simanggaris, Nunukan, Sebatik, Long Midang Krayan, Long Nawang dan Long Pahangai) menunjukkan sistem kelembagaan masih bersifat sentralis, karena tidak dilakukan oleh Kementerian Perhubungan atau Kementerian Pekerjaan Umum. Hal ini menunjukkan terjadi power interplay antar lembaga dalam pembangunan perbatasan. Terlebih lagi keanggotaan BNPP yang terdiri dari 15 kementerian dan lembaga negara serta 13 provinsi, juga BNPP membentuk Gugus Tugas Pengelola Perbatasan yang bersifat ad hoc dengan 32 kementerian dan lembaga negara (Keputusan Kepala BNPP Nomor 816.05-115 Tahun 2014).

Power interplay BNPP dengan kementerian antara lain meliputi pada Kementerian Pertahanan, Kementerian Luar Negeri, Kementerian Pekerjaan Umum dan Kementerian Kehutanan. Pada Kementerian Pertahanan, Menteri Pertahanan, Purnomo mengatakan: 
Dengan dibentuknya BNPP maka fungsi BNPP tumpang tindih dengan General Border Committe (GBC) yang dikepalai oleh Menteri Pertahanan (Menhan) yang selama ini berjalan. Beberapa fungsi GBC dikelola oleh BNPP dan sebaliknya. GBC selain bergerak pada bidang militer dan intelejen serta batas negara juga mengelola sektor sosial dan ekonomi ke dua negara (Malaysia-Indonesia) yang disebut SOSEK MALINDO. Berbagai lembaga masuk dalam GBC, keimigrasian, bea-cukai, perhubungan dan Mendagri. Setelah terbentuk BNPP, tidak ada aturan maupun kebijakan yang memperjelas hal tersebut. Tumpang tindihnya fungsi ke dua lembaga ini perlu segera diselesaikan karena dikuatirkan memperlemah peran keduanya. (Moeldoko, 2014:290).

Sedangkan power interplay BNPP dengan Pemda Provinsi dan Kabupaten juga terjadi. Provinsi Kalimantan Timur tahun 2009 telah membentuk badan perencanaan dan pembangunan kawasan perbatasan dengan nama Badan Pengelola Kawasan Perbatasan, Pedalaman dan Daerah Tertinggal (BPKP2DT) dan Kalimantan Barat tahun 2008 sebelum pemerintah membentuk BNPP tahun 2011.

Kedua, adalah terjadi perbedaan prioritas kebijakan dan kepentingan program pembangunan infrastruktur yang diusulkan oleh Pemerintah Daerah. Perbedaan ini terjadi sebagai hasil pilihan kebijakan politik pemerintah pusat berdasarkan hasil pembahasan dan kesepakatan dengan DPR RI (Risalah Raker Komisi II DPR RI tahun 2012). Karena pembangunan jalan di Krayan Kabupaten Nunukan berada pada kawasan hutan lindung Taman Nasional Krayan Mentarang (TNKM) yang telah ditetapkan pemerintah pada tahun 1996, maka alternatif pilihan politik pemerintah pusat adalah membangun perluasan bandara Yuvai Semaring di Krayan pada tahun anggaran 2012 dan 2013 sebesar Rp.120 Miliar, termasuk pembangunan Bandara Long Apung Malinau dan Bandara Data Dawai di Kutai Barat Kalimantan Timur tahun anggaran 2013-2014 (www.bappeda.kaltim.go.id).

Secara politik, kepentingan Pemerintah Pusat membangun perluasan bandara dan jalan perbatasan kerja sama dengan TNI-AD berkaitan dengan aspek keamanan yang sangat diperlukan untuk mendukung kekuatan penjagaan keamanan di kawasan perbatasan Kalimantan Long Midan Kecamatan Krayan yang belum ada kantor imigrasi (Pintu Lintas Batas/PLB) resmi. Artinya keberadaan militer akan mendukung dan memperkuat tugas-tugas keimigrasian (Wawancara Pejabat Imigrasi, Suriansyah di Nunukan) dan akan memudahkan transportasi dan mobilisasi kebutuhan militer di perbatasan guna membantu tugas keimigrasian. Hal ini penting karena 
masyarakat banyak yang keluar masuk perbatasan Malaysia. Kondisi tersebut tentunya tidak menjamin dan tidak menguntungkan bagi keamanan dan kedaulatan NKRI.

Tabel 1. Pos Lintas Batas (PLB) di Provinsi Kalimantan Barat, Kalimantan Timur, dan Kalimantan Utara

\begin{tabular}{|c|c|c|c|c|}
\hline Provinsi & Kabupaten & Kecamatan & $\begin{array}{l}\text { Nama Pos Lintas } \\
\text { Batas }\end{array}$ & $\begin{array}{l}\text { Klasifikasi/ } \\
\text { Tipe PLB }\end{array}$ \\
\hline \multirow[t]{10}{*}{$\begin{array}{l}\text { Kalimantan } \\
\text { Barat }\end{array}$} & \multirow[t]{2}{*}{ Sambas } & Paloh & $\begin{array}{l}\text { 1. Temajuk } \\
\text { 2. Liku }\end{array}$ & $\begin{array}{l}\text { Tradisional/Laut } \\
\text { Tradisional/Laut }\end{array}$ \\
\hline & & $\begin{array}{l}\text { Sajingan } \\
\text { Besar }\end{array}$ & $\begin{array}{l}\text { 1. Sajingan } \\
\text { 2. Aruk }\end{array}$ & $\begin{array}{l}\text { Tradisional/Darat } \\
\text { Tradisional/Darat }\end{array}$ \\
\hline & \multirow[t]{2}{*}{ Bengkayang } & Seluas & $\begin{array}{l}\text { 1. Siding } \\
\text { 2. Jagoibabang }\end{array}$ & $\begin{array}{l}\text { Tradisional/Darat } \\
\text { Tradisional/Darat }\end{array}$ \\
\hline & & Sarapan & Sarapan & Tradisional/Darat \\
\hline & \multirow[t]{2}{*}{ Sanggau } & Entikong & $\begin{array}{l}\text { 1. Entikong } \\
\text { 2. Segumon }\end{array}$ & $\begin{array}{l}\text { Internasional/Darat } \\
\text { (Resmi) } \\
\text { Tradisional/Darat }\end{array}$ \\
\hline & & Sekayam & Bantan & Tradisional/Darat \\
\hline & \multirow[t]{2}{*}{ Sintang } & $\begin{array}{l}\text { Ketungau } \\
\text { Hulu }\end{array}$ & $\begin{array}{l}\text { 1. Jasa } \\
\text { 2. Nanga Bayan }\end{array}$ & $\begin{array}{l}\text { Tradisional/Darat } \\
\text { Tradisional/Darat }\end{array}$ \\
\hline & & $\begin{array}{l}\text { Ketungau } \\
\text { Tengah } \\
\end{array}$ & Semareh & Tradisional/Darat \\
\hline & \multirow[t]{2}{*}{$\begin{array}{l}\text { Kapuas } \\
\text { Hulu }\end{array}$} & $\begin{array}{l}\text { Puring } \\
\text { Kencana }\end{array}$ & $\begin{array}{l}\text { 1. Merakai Panjang } \\
\text { 2. Langau }\end{array}$ & $\begin{array}{l}\text { Tradisional/Darat } \\
\text { Tradisional/Darat }\end{array}$ \\
\hline & & Badau & Nanga Badau & Tradisional/Darat \\
\hline $\begin{array}{l}\text { Kalimantan } \\
\text { Timur }\end{array}$ & Kutai Barat & Long Apari & Lasan Tuyan & Tradisional/Darat \\
\hline \multirow[t]{7}{*}{$\begin{array}{l}\text { Kalimantan } \\
\text { Utara }\end{array}$} & Malinau & $\begin{array}{l}\text { Krayan } \\
\text { Hulu }\end{array}$ & $\begin{array}{l}\text { Long Nawang } \\
\text { Apau Ping }\end{array}$ & $\begin{array}{l}\text { Tradisional/Darat } \\
\text { Tradisional/Darat }\end{array}$ \\
\hline & \multirow[t]{6}{*}{ Nunukan } & Nunukan & Nunukan & $\begin{array}{l}\text { Internasional/Darat } \\
\text { (Resmi) }\end{array}$ \\
\hline & & $\begin{array}{l}\text { Sei } \\
\text { Pancang }\end{array}$ & Sungai Pancang & Tradisional/Darat \\
\hline & & Pujungan & Apau Ping & Tradisional/Darat \\
\hline & & Lumbudut & $\begin{array}{l}\text { 1. Long Layu } \\
\text { 2. Long Midang }\end{array}$ & $\begin{array}{l}\text { Tradisional/Darat } \\
\text { Tradisional/Darat }\end{array}$ \\
\hline & & Krayan & $\begin{array}{l}\text { 1. Labang } \\
\text { 2. Long Bawan }\end{array}$ & $\begin{array}{l}\text { Tradisional/Darat } \\
\text { Tradisional/Darat }\end{array}$ \\
\hline & & Lumbis & $\begin{array}{l}\text { 1. Simanggaris } \\
\text { 2. Tau Lumbis }\end{array}$ & $\begin{array}{l}\text { Tradisional/Darat } \\
\text { Tradisional/Darat }\end{array}$ \\
\hline
\end{tabular}

Sumber : Peraturan BNPP Nomor 2 Tahun 2011, Rencana Induk Tahun 2011-2014

Pada tabel 1 menunjukkan banyaknya jumlah pos lintas batas yang sangat perlu adanya pengamanan dari pihak keimigrasian maupun TNI, karena hanya ada dua Pos Lintas Batas (PLB) yang resmi, sedangkan yang lain hanya bersifat tradisional yang terjadi antar ke dua negara dan perlu perhatian dari aspek keamanan. 
Tabel 2. Pos Pengamanan Perbatasan di Provinsi Kalimantan Barat dan Kalimantan Timur dan Kalimantan Utara

\begin{tabular}{|c|c|c|c|}
\hline No & Kabupaten/Kota & \multicolumn{2}{|c|}{ Nama Pos Pengamanan Perbatasan (Pamtas) } \\
\hline A & \multicolumn{3}{|l|}{ KALIMANTAN BARAT } \\
\hline 1 & Sambas & $\begin{array}{l}\text { 1. Temajuk } \\
\text { 2. S. Besar }\end{array}$ & $\begin{array}{l}\text { 3. Aruk } \\
\text { 4. Gabma Biawak }\end{array}$ \\
\hline 2 & Bengkayang & $\begin{array}{l}\text { 1. Siding } \\
\text { 2. Jagoi Babang }\end{array}$ & 3. Sapadu \\
\hline 3 & Sanggau & $\begin{array}{l}\text { 1. Entikong } \\
\text { 2. Segumun }\end{array}$ & $\begin{array}{l}\text { 3. Bawang } \\
\text { 4. Gabma Entikong }\end{array}$ \\
\hline 4 & Sintang & $\begin{array}{l}\text { 1. Jasa } \\
\text { 2. Nangabayan }\end{array}$ & 3. Semareh \\
\hline 5 & Kapuas Hulu & $\begin{array}{l}\text { 1. Merakai Panjang } \\
\text { 2. Langau }\end{array}$ & $\begin{array}{l}\text { 3. Badau } \\
\text { 4. Gabma L. Antu }\end{array}$ \\
\hline $\mathrm{B}$ & \multicolumn{3}{|l|}{ KALIMANTAN TIMUR } \\
\hline 6 & Kutai Barat & 1. Long Apari & \\
\hline $\mathrm{C}$ & \multicolumn{3}{|l|}{ KALIMANTAN UTARA } \\
\hline 7 & Malinau & $\begin{array}{l}\text { 1. Apauping } \\
\text { 2. Long Pujungan } \\
\text { 3. Long Ampung }\end{array}$ & $\begin{array}{l}\text { 4. Long Nawang } \\
\text { 5. Long Betaoh }\end{array}$ \\
\hline 8 & Nunukan & $\begin{array}{l}\text { 1. Nunukan } \\
\text { 2. Lumbis } \\
\text { 3. Sei Ular } \\
\text { 4. Sei Kaca } \\
\text { 5. Bambangan Besar } \\
\text { 6. Aji Kuning } \\
\text { 7. Bukit Kramat } \\
\text { 8. Tanjung Aru } \\
\text { 9. Kanduangan } \\
\text { 10.Simanggaris Gab }\end{array}$ & $\begin{array}{l}\text { 11.Simanggaris Lama } \\
\text { 12.Tembalang } \\
\text { 13.Sebuku } \\
\text { 14.Sei Agison } \\
\text { 15.Simantobol } \\
\text { 16.Simantipal } \\
\text { 17.Labang } \\
\text { 18.Long Bawan } \\
\text { 19.Krayan } \\
\text { 20.Gabma Seliku }\end{array}$ \\
\hline
\end{tabular}

Sumber : Peraturan BNPP Nomor 2 Than 2011, Rencana Induk Tahun 2011-2014

Kepentingan pemerintah pada aspek keamanan yang kedua adalah untuk mendukung kekuatan keamanan pada Pos Pengamanan Perbatasan (Pos Pamtas) yang berada di sepanjang garis perbatasan $2.004 \mathrm{~km}$ di Kalimantan yang meliputi Kalimantan Barat, Kalimantan Timur dan Kalimantan Utara yang berbatasan dengan Negara Bagian Serawak dan Sabah Malaysia.

Pada Tabel 2 menunjukkan bahwa sepanjang garis perbatasan di Kalimantan terdapat 44 Pos Pengamanan Perbatasan pada garis sepanjang 2004 km. Hal ini sangat penting bagi negara karena garis perbatasan sepanjang $2004 \mathrm{~km}$ tersebut, hanya terdapat 44 Pos Pamtas sehingga rata-rata tiap Pos Pamtas harus bertanggung jawab sepanjang sekitar 45,5 $\mathrm{km}$ dengan kondisi alam perbatasan yang medannya sangat sulit karena terdiri dari kawasan hutan dan sungai-sungai serta kelengkapan 
persenjataan yang sangat minim. Tentu tanggung jawab ini tidak mudah mengingat perbatasan Kalimantan dengan Malaysia merupakan kawasan perbatasan yang keluar masuknya orang dan barang sangat tinggi, sehingga dipandang perlu adanya pengamanan yang ketat pada daerah kawasan perbatasan Kalimantan dengan Malaysia agar tidak terjadi tindakan ilegal dan mengganggu keamanan dan kedaulatan NKRI.

Pos Pamtas paling banyak di Kabupaten Nunukan sejumlah 20 Pos Pamtas, (Peraturan BNPP Nomor 2 Tahun 2011, Rencana Induk Tahun 2011-2014). Penguatan Pos Pamtas sangat penting dan strategis karena pada sejumlah jalur pos lalu lintas batas masih banyak yang bersifat jalur lintas batas tidak resmi (jalur tikus), maka TNI dapat menggunakan Bandara Yuvai Semaring, Bandara Long Apung Malinau dan Bandara Data Dawai di Kutai Barat untuk keperluan kemiliteran TNI dalam rangka memperkuat pengamanan PLB dan keberadaan Pos Pamtas terhadap ancaman kejahatan transnasional dan mengimbangi kekuatan pos perbatasan Malaysia yang sudah lebih baik.

Sedangkan kepentingan pemerintah pusat pada aspek strategis geografi dari prioritas kebijakan pembangunan Bandara Yuvai Semaring bekerjasama dengan TNI-AD (http://klipinghankam.com/2012), karena pertimbangan kepentingan strategis nasional secara geostrategi, geopolitik dan geoekonomi maupun geografi (Grand Design BNPP 2011-2025:14). Secara geostrategi, pembangunan bandara oleh TNI-AD karena kepentingan negara untuk memperkuat pertahanan dan keamanan di kawasan perbatasan Kalimantan Utara dan Kalimantan Timur. Secara geopolitik, untuk memperkuat Wawasan Nusantara dan politik luar negeri Indonesia terhadap Malaysia. Secara goegrafis, TNI-AD dinilai memahami kondisi geografi wilayah perbatasan Kalimantan, karena secara politik TNI memiliki pengalaman di Kalimantan saat konfrontasi 1963-1967 dan TNI-AD memiliki kemampuan membangun bandara (Citrawijaya, 2005:5). Dan secara geoekonomi, menjadi pintu bagi investasi pengembangan kawasan ekonomi perbatasan di Kalimantan dan sekitarnya yang kaya sumber daya alam.

Selanjutnya kepentingan Pemerintah Pusat pada pembangunan infrastruktur di perbatasan Kalimantan untuk penguatan rasa nasionalisme masyarakat perbatasan. Perbatasan Kalimantan merupakan "Beranda Terdepan NKRI" maka harus dibangun guna meningkatkan kesejahteraan, nasionalisme, keamanan dan 
kedaulatan NKRI. Dampak aktivitas masyarakat perbatasan di Malaysia dalam rangka pemenuhan kehidupan sehari-hari memberikan dampak pada terjadinya perubahan pada nilai-nilai nasionalisme masyarakat perbatasan seperti penggunaan bahasa, mata uang dan penggunaan simbol-simbol yang digunakan sehingga terjadi pergeseran dan disorientasi nilai-nilai nasionalisme. Pengalaman sejarah lepasnya Pulau Sipadan dan Ligitan menjadi pelajaran bahwa wilayah perbatasan harus dikelola pemerintah pusat dengan baik dan nyata bagi kepentingan masyarakat perbatasan. Oleh karena itu, sekecil apa pun wilayah perbatasan Indonesia, maka pemerintah harus mengelola perbatasan bagi kepentingan masyarakat dan kedaulatan NKRI.

Pembangunan infrastruktur perbatasan era Pemerintahan SBY 2009-2014 dinilai lamban, bahkan dirasa tidak memberikan pengaruh signifikan pada masyarakat, sehingga masyarakat masih merasa kesulitan dalam aktivitas kehidupan dan tetap ke Malaysia untuk pemenuhan kebutuhan pokok. Masyarakat perbatasan Kalimantan lebih berorientasi kepada Malaysia, karena memiliki akses yang lebih baik sehingga masyarakat merasa lebih dekat, lebih mudah dan lebih murah daripada ke ibukota Kabupaten Nunukan, Tarakan atau Entikong yang lebih jauh jaraknya. Kaitan pembangunan perbatasan dan nasionalisme serta kesiapan menghadapi AEC 2015, Menko Perekonomian Hatta Rajasa, mengatakan bahwa :

\begin{abstract}
AEC 2015 menyimpan tantangan sekaligus peluang yang harus meningkatkan rasa nasionalisme dan kebanggaan sebagai bangsa. Nasionalisme dan kebanggaan tersebut tidak akan terbangun bilamana titik tumpu pembangunan kawasan perbatasan tidak dilaksanakan. Untuk itu, pemerintah harus mampu menyediakan berbagai infrastruktur dan fasilitas yang setara dengan kawasan perbatasan Malaysia agar tidak melunturkan semangat kebangsaan warga masyarakat Indonesia di kawasan perbatasan. (Moeldoko, 2014:267).
\end{abstract}

Kehadiran BNPP dipandang sebagai lembaga yang sangat penting dalam rangka penanganan masalah perbatasan. Perspektif ini mempertegas peran negara yang terkait dengan teori negara bahwa negara memiliki otoritas dan tanggung jawab (Miliband, 1969:69) yang dilaksanakan melalui institusi melalui kebijakan pemerintahan atas nama negara (Skocpol dan Winters, 1991:22), untuk memberikan pelayanan kepada rakyat. Masalah perbatasan berkaitan erat dengan kedaulatan negara, bila kawasan perbatasan terganggu maka kedaulatan negara juga dapat terganggu. 
Sedangkan dalam konteks hubungan pusat dan daerah, pemerintah pusat harus mendistribusikan kekuasaannya pada pemerintah daerah untuk melaksanakan pembangunan yang sesuai kewenangannya. Hal ini mempertegas kewenangan pemerintah daerah seperti yang disampaikan oleh Smith bahwa desentralisasi berhubungan dengan tingkat kekuasaan dan kewenangan yang diserahkan melalui hirarkhi geografis negara dan institusi-institusi dan proses di mana penyerahan tersebut terjadi (Brian C. Smith, 1985:1). Oleh karena itu adalah kewajiban pemerintah daerah untuk mengusulkan kewenangannya kepada pemerintah pusat yang berkaitan dengan pembangunan kawasan perbatasan yang telah dilaksanakan melalui rapat-rapat koordinasi kawasan perbatasan dan Musrenbangda serta Musrenbangnas.

Namun demikian, dalam implementasi kebijakan selalu terjadi ketidaksesuaian dengan kebijakan yang telah ditetapkan, sehingga apa yang menjadi harapan tidak menjadi kenyataan. Hal inilah yang terjadi pada pembangunan infrastruktur di perbatasan Kalimantan untuk kesejahteraan masyarakat, namun karena kebijakan ditetapkan oleh pemerintah pusat (terjadi power interplay), maka kepentingan nasional menjadi prioritas negara di perbatasan walaupun sangat penting bagi masyarakat.

Hal ini menunjukkan bahwa hubungan kekuasaan pemerintah pusat dan daerah dalam pembangunan infrastruktur perbatasan Kalimantan Indonesia-Malaysia masih menjadi dominasi pemerintah pusat (kementerian) atas nama kepentingan nasional. Dengan adanya kerja sama pemerintah dengan TNI-AD juga menunjukkan terjadinya power interplay antar lembaga di tingkat pusat. Hal ini terjadi karena peran BNPP sebagai lembaga negara adalah lemah hanya bersifat koordinatif yakni mengkoordinasikan perencanaan dan pelaksanaan pembangunan perbatasan. Sedangkan pengambil kebijakan ada pada kementerian teknis yang sekaligus sebagai lembaga pelaksana pembangunan di perbatasan, sehingga terjadi ego sektoral antar kementerian. Skocpol mengatakan bahwa negara adalah suatu arena politik disebabkan para aktor yang beroperasi di dalam arena tersebut menggunakan sarana yang berbedabeda, seperti paksaan atau slogan yang mengatasnamakan kebijakan umum (Theda Skocpol dan Winters, 1991:21), maka kebijakan nasional merupakan salah satu bentuk dari slogan. 
Pemerintah pusat masih fokus pada aspek politik dan keamanan serta kedaulatan negara sebagai dasar penetapan kebijakan kepentingan strategis nasional yang meliputi aspek geostrategi, geopolitik dan geoekonomi (Peraturan BNPP Nomor 1 Tahun 2011:14). Hal ini menunjukkan bahwa pembangunan perbatasan belum dilaksanakan sesuai dengan kebijakan yang ditetapkan oleh pemerintah yang menyatakan bahwa pembangunan perbatasan berdasarkan pada paradigma pendekatan kesejahteraan, keamanan dan lingkungan (Peraturan BNPP Nomor 1 Tahun 2011:1618). Artinya pembangunan perbatasan harus diprioritaskan pada aspek kesejahteraan bukan pada prioritas keamanan.

Perbatasan merupakan daerah urgen kontrol politik dan keamanan bagi negara, bahkan juga negara tetangga, serta sebagai identifikasi kekuatan atau kelemahan negara yang dapat diukur dari kemampuan negara mengelola perbatasannya, terutama perbatasan yang rawan konflik. Serta dapat dijadikan tolak ukur kemampuan negara mempertahankan kedaulatannya karena wilayah perbatasan merupakan salah satu simbol de jure maupun de facto batas terjauh kedaulatan teritorial negara (Wardhani dalam Madu, 2010:64). Namun political will pemerintah dalam mempercepat proses pembangunan infrastruktur perbatasan masih sangat rendah, karena belum menikmati akses kemudahan dan kesejahteraan pada masyarakat perbatasan.

Pembangunan perbatasan dan nasionalisme penting, bila ada pembangunan jalan tentu dapat mempersatukan masyarakat perbatasan yang terisolasi dengan masyarakat wilayah lain, bila pendidikan baik akan membuka wawasan kebangsaan terhadap eksistensi negara dan cinta tanah air. Semakin besar pembangunan di perbatasan maka semakin besar juga rasa kebanggaan pada negara. Pembangunan merupakan simbol kehadiran negara yang dapat meningkatkan rasa nasionalisme masyarakat terhadap negara dan wujud kedaulatan NKRI.

\section{Kesimpulan}

Kepentingan Pemerintah Pusat dalam pembangunan infrastruktur perbatasan Kalimantan Indonesia-Malaysia era Presiden Susilo Bambang Yudhoyono tahun 2009-2014 masih menjadi dominasi pemerintah pusat yakni pada kementerian terkait, karena perbatasan menjadi tanggung jawab negara sehingga terjadi power interplay dan peran BNPP hanya koordinatif. Terjadi perbedaan prioritas dan kepentingan 
pusat, karena Pemerintah Pusat masih fokus pada aspek politik, keamanan dan kedaulatan NKRI.

Dengan demikian pembangunan infrastruktur perbatasan Kalimantan Indonesia-Malaysia era Presiden Susilo Bambang Yudhoyono tahun 2009-2014 belum memberikan dampak signifikan pada kemajuan daerah perbatasan dan kesejahteraan masyarakat kawasan perbatasan Kalimantan Indonesia-Malaysia.

\section{Saran}

1. Pemerintah pusat sebaiknya membuat regulasi tentang pembagian kekuasaan kepada pemerintah daerah kabupaten perbatasan dalam pembangunan infrastruktur perbatasan, sehingga azas otonomi daerah berjalan dengan baik pada kabupaten perbatasan. Semacam "Otonomi Perbatasan" yakni kewenangan tertentu yang diperoleh pada kabupaten perbatasan untuk mempercepat proses pembangunan perbatasan.

2. Pemerintah pusat sebaiknya membuat regulasi yang dapat memperkuat peran dan fungsi BNPP, sehingga pembangunan infrastruktur perbatasan dapat dilaksanakan dengan segera dan baik guna mencapai kesejahteraan masyarakat, keamanan dan kedaulatan NKRI

\section{Daftar Rujukan}

\section{Buku}

Andrews, C. M. dan Ichlasul A. (ed). (1993). Hubungan Pusat-Daerah Dalam Pembangunan. Jakarta: Rajawali Grafindo Persada.

Bakri, S. U. (1999). Pengantar Hubungan Internasional. Jakarta: Jayabaya University Press. Budiarjo, M. (2004). Dasar-Dasar Ilmu Politik. Jakarta: Gramedia Pustaka.

Chandhoke, N. (1995). Benturan Negara dan Masyarakat Sipil. Yogyakarta: Istawa.

Citrawijaya, S. (2005). Kompi X di Rimba Siglayan: Konfrontasi dengan Malaysia. Jakarta: Penerbit Buku Kompas.

Heaton, C. \& Ernest R. (1990). 20 Century Thinker on Nationalism and $19^{\text {th }}$ Century Orientalist. United Kingdom: Departement of Theoritical and Applied Linguistic, University of Edinburgh.

Jemadu, Al. (2008). Politik Global Dalam Teori dan Praktek. Yogyakarta: Graha Ilmu. 
Jenkins, W. I. (1978). Policy Analysis Oxford: Martin Robertson.

Kahin, G. M. (1980). Nasionalisme dan Revolusi di Indonesia. Kuala Lumpur: Dewan Bahasa dan Pustaka Kementerian Pelajar Malaysia.

Kellas, J. G. (1998). The Politic of Nationalism and Ethnicity. Macmillan Press Ltd.

Madu, L., et.al. (2010). Mengelola Perbatasan Indonesia di Dunia Tanpa Batas: Isu, Permasalahan dan Pilihan Kebijakan. Jakarta: Graha Ilmu.

Magenda, B. D. (1991). East Kalimantan; The Decline Of A Commercial Aristocracy, Cornell Modern Indonesian Project, Cornell University. New York: Ithaca.

Miliband, R. (1969). The State in Capitalist Society. New York: Basic Book Inc.

Moeldoko. (2014). Kebijakan dan Scenario Planning Pengelolaan Kawasan Perbatasan di Indonesia 2030: Studi Kasus Perbatasan Darat di Kalimantan. Jakarta: Disertasi Program Ilmu Administrasi FISIP UI.

Persons, W. (2008). Public Policy: Pengantar Teori dan Praktek Analisa Kebijakan. Jakarta: Kencana.

Pimpinan MPR dan Tim Kerja Sosialisasi MPR Periode 2009-2014. (2012). Empat Pilar Kehidupan Berbangsa dan Bernegara. Jakarta: Sekrtariat Jenderal MPR RI.

Pressman, J. dan Wildavsky A. (1984). Implementation. Berkeley: University of California Press.

Skocpol, T. (1991). Negara dan Revolusi Sosial: Suatu Analisis Komperatif Tentang Perancis, Rusia dan Cina. Jakarta: Erlangga.

Shabbir, C., G. \& Dennis R. (1983). Decentralization and Development Policy Implementation in Developing Countries. Beverly Hills/London/New Delhi: Sage Publications.

Smith, B. C. (1985). Decentralization: The Territorial Dimention of The State. London. George Allen and Unwin.

Subarsono, A. G. (2009). Analisis Kebijakan Publik: Konsep, Teori dan Aplikasi. Yogyakarta: Pustaka Pelajar.

Wahab, S. A. (2001). Analisis Kebijaksanaan: Dari Formulasi ke Implementasi Kebijaksanaan Negara. Jakarta: Bumi Aksara.

Wetherly, Paul. (2005). Marxism and The State Analytical Approach. New York. Palgrave Macmillan. 
Wardhani, B. L. S. W. (2010). "Revisi Teritorial, Eksternalisasi Konflik Etnis dan Keamanan Perbatasan", dalam Ludiro Madu, dkk. 2010. Mengelola Perbatasan Indonesia di Dunia Tanpa Batas: Isu, Permasalahan dan Pilihan Kebijakan. Jakarta: Graha Ilmu

\section{Undang-Undang dan Peraturan Pemerintah}

Undang-Undang RI Nomor 43 Tahun 2008 Tentang Wilayah Negara.

Peraturan Presiden RI Nomor 12 Tahun 2010 Tentang BNPP.

Peraturan Presiden RI Nomor 5 Tahun 2010 Tentang RPJM Nasional 2010-2014.

Peraturan Presiden RI Nomor 31 Tahun 2015 Tentang Rencana Tata Ruang Kawasan Perbatasan Negara di Kalimantan.

Peraturan BNPP Nomor 1 Tahun 2011 Tentang Grand Design Pengelolaan Batas Wilayah Negara dan Kawasan Perbatasan Tahun 2011-2025.

Peraturan BNPP Nomor 2 Tahun 2011 Tentang Rencana Induk Tahun 2011-2014.

Peraturan BNPP Nomor 2 Tahun 2012 Tentang Rencana Aksi Pembangunan Infrastruktur Kawasan Perbatasan Tahun 2012, Tanggal : 6 Januari 2012

Peraturan BNPP Nomor 1 Tahun 2013 Tentang Rencana Aksi Pengelolaan Batas Wilayah Negara dan Kawasan Perbatasan Tahun 2013, Tanggal 28 Januari 2013.

Peraturan BNPP Nomor 6 Tahun 2014 Tentang Rencana Aksi Pengelolaan Batas Wilayah Negara dan Kawasan Perbatasan Tahun 2014, Tanggal 11 April 2014.

Berita Negara RI Nomor 44 Tahun 2011, Peraturan BNPP Nomor 1 Tahun 2011 Tentang Desain Besar Pengelolaan Batas Wilayah Negara dan Kawasan Perbatasan Tahun 2011-2025.

Departemen Kehutanan, 2002. Rencana Pengelolaan Taman Nasional Krayan Mentarang 2002-2025. Direktorat Perlindungan Hutan dan Konservasi Alam, Jakarta.

Keputusan Kepala BNPP Nomor 816.05-115 Tahun 2014 Tentang Pembentukan Gugus Tugas Pengelolaan Perbatasan Wilayah Negara dan Kawasan Perbatasan. 
Risalah RDP Komisi II DPR RI dengan Sekjen Kemendagri dan Sekretaris BNPP (RKA K-L Tahun 2012) tertanggal 21 Oktober 2011.

Risalah Rapat Kerja Komisi II DPR RI dengan BNPP tanggal 27 Januari 2012,

Risalah Rapat Komisi II DPR RI dengan Menteri Dalam Negeri dan Kepala BNPP tanggal 6 Maret 2012.

\section{Harian Surat Kabar dan Media}

Desa Diklaim, RI Tempuh Jalur Hukum. Republika. 15 November 2014.

Sulitnya Hidup Layak di Tanah Air. Republika. 15 November 2014.

TNI Bangun bandara di perbatasan Malaysia, 23 April 2012 dalam http://klipinghankam. com/2012_04_01_archive.html diakses tgl 20 Sept 2012.

http://www.bappeda.kaltim.go.id/miliaran-untuk-masyarakat-krayan.htm diakses tanggal 28 Febuari 2013.

http://www.diskominfo.kaltimprov.go.id diakses tanggal 19 Oktober 2015.

http://www.wwf Indonesia Krayan Mentarang, 2014. 